\title{
Commercial utilization of mineral waste: review of analysis methods determining its compliance with environmental laws
}

\author{
Agnieszka Gruszecka-Kosowska, Bartosz Mikoda \\ University of Science and Technology AGH, Faculty of Geology, Geophysics and Environmental Protection, Department of \\ Environmental Protection; al. A. Mickiewicza 30, 30-059 Krakow, Poland; e-mail: agnieszka.gruszecka@agh.edu.pl
}

(C) 2015 Authors. This is an open access publication, which can be used, distributed and reproduced in any medium according to the Creative Commons CC-BY 4.0 License requiring that the original work has been properly cited.

Received: 26 May 2015; accepted: 27 July 2015

\begin{abstract}
Optimal methods used in the analysis of waste material resulting from mining and processing of mineral resources that allow to assess the potential impact of waste on the environment, based on binding environmental laws regulating potential commercial utilization of waste were investigated. The paper is concerned mostly with mineral waste, constituting about $80 \%$ of all industrial waste generated. According to the principles of sustainable waste management, waste storage is considered to be the last resort. However, every year over $20 \%$ of the total amount of industrial waste generated is stored. That makes the amount of the already deposited materials, coming from the time when the commercial utilization was not common in Poland, even more considerable. When it comes to extensive, i.e. regarding great quantities, and long-term usage of industrial wastes, the identical composition of waste material coming from different batches is of the essence. Unfortunately, this condition is not always fulfilled, therefore chemical composition analyses need to be carried out for monitoring purposes. For the same reason the waste material used should also be tested to check whether the parameters of a given batch are within the limit values defined by the standards. Described methods are intended to facilitate waste characterisation with respect to their effect on the environment when used for commercial purposes. An individual method is never good enough to determine the full extent of environmental impact. It is therefore recommended to apply several methods in a logical sequence, depending on the type of waste material and its purpose.
\end{abstract}

Keywords: waste utilization, mineral waste, mineralogical-chemical research, economic use of waste

\section{INTRODUCTION}

The search for possible waste utilization methods with an economic potential is mainly related to the inconvenience caused by landfill sites and shrinking natural resources. To be able to utilize waste material economically not only particular technical requirements, specific for a given industrial process, determining whether a material can be reused need to be met, but also specific environmental requirements guaranteeing that the commercial utilization will not pose any threat to the environment.

From a technological point of view, the potential utilization of a given waste material is de- termined on the basis of a quantitative and qualitative analysis. The commercial utilization of the waste material that meets these requirements cannot ultimately pose any threat to the environment. In order to determine a potential impact of waste material on the environment, methods of analysis are applied and their results are interpreted according to environmental laws and regulations.

Pursuant to the definition found in the fundamental legal act in Poland on waste - Ustawa $z$ dnia 14 grudnia 2012 r. o odpadach, waste materials are defined as substances or materials that the owner of which intends to dispose of or is obliged to dispose of. In Poland industrial waste constitutes 
about $90 \%$ of all the waste material produced, and in 2013 there were $132 \mathrm{mln} \mathrm{Mg}$ out of the total of $143 \mathrm{mln} \mathrm{Mg}$ of all the waste generated that year (GUS 2014). Industrial waste material is primarily generated by mining, energy and metallurgy sectors, and they are also by-products of industrial processes (Rosik-Dulewska 2012). Due to the its considerable amount, industrial waste constitutes a significant issue from the point of view of environment protection. At the same time, a great diversity of the waste materials available requires verification of technical parameters that make the waste potentially suitable for commercial utilization. It also needs to be determined whether such action is environmentally safe. According to the principles of sustainable waste management, waste storage is considered to be the last resort (Kicińska et al. 2014). However, every year over $20 \%$ of the total amount of industrial waste generated is stored. That makes the amount of the already deposited materials, coming from the time when the commercial utilization was not common in Poland, even more considerable.

The aim of this article is to review optimal methods used in the analysis of waste material resulting from mining and processing of mineral resources that allow to assess the potential impact of waste on the environment. This review is based on binding environmental laws regulating potential commercial utilization of waste. The following paper is concerned mostly with mineral waste, constituting about $80 \%$ of all industrial waste generated. The definition of mineral waste material has been amended and it no longer refers to the mineral waste i.e. waste belonging to group code 01 - waste from mining and processing, but it also refers to mineral waste in broader context i.e. waste from groups with codes 10 01-10 08 and 10 11-10 13 - waste from energy and metallurgy sector, ceramics industry and mineral resources retrieved from waste (Galos \& Nieć 2009).

\section{DIRECTIONS IN COMMERCIAL UTILIZATION OF MINERAL WASTE}

One of the most fundamental areas where mineral waste can be utilized is construction. First of all, it can be used as a component of concrete, in which the aggregate constitutes $70-80 \%$ of concrete volume and significantly affects the properties of the concrete mix, and later of hardened concrete (Kohutek 2008). The gradation of a concrete mix should be selected in such a way that it exhibits maximum water tightness and workability with the minimal amount of water and cement used. Grain-size distribution curves are used to choose these parameters (Szymański \& Kołakowski 1992). In practice, it means that mineral waste of various particle-size fractions can be used as an aggregate in concrete production, from gravel fraction to dust fraction. Although, the specifications concerning chemical composition of waste materials that could be used in the place of clinker are even more strictly defined, many types of waste materials are currently used for this purpose (Małolepszy et al. 1994, Helios-Rybicka et al. 2013). Using waste material as a component of concrete is the most popular solution, not only because of the fact that concrete is and will be the most commonly used material in construction. But it also results from the fact that its structure after the binding process is well solidified and its strength make it impossible for various pollutions to be transferred into the environment, immobilizing them effectively (Li et al. 2001, Batchelor 2006, Król 2006). Yet another area with a great development potential is road construction because of the fact that many kilometres of roads are planned to be built. Mineral waste materials could be used to stabilize (after being transformed into slaked lime $\left.\mathrm{Ca}(\mathrm{OH})_{2}\right)$ and drain land (after being transformed into quicklime $\mathrm{CaO}$ ) (PN-S-96011:1998), or to build soil banks for road construction purposes or to improve their parameters (Sybilski \& Kraszewski 2004). Waste materials can be used in road construction, in aggregate production and even instead of sand during abrasive blasting in repair shipyards (Andziak \& Sobczyński 2001, Gruchot \& Zawisza 2007, Galos 2008, Góralczyk et al. 2009). Environmental protection offers some perspectives for mineral waste materials to be used on a larger scale. First of all, they can be used as pollution sorbents, for example in desulfurization of flue gases in industry (Dehghani \& Bridjanian 2010, Özyuğuran \& Ersoy-Meriçboyu 2012), in $\mathrm{CO}_{2}$ capture in CCS projects (Wdowin \& Gruszecka 2012, Wdowin et al. 2012), to capture pollutants from sewage or in the process of land remediation (Żygadło et al. 2010, 
Franus et al. 2014). Waste material from energy sector, especially fly ashes because of their pozzolanic and thixotropic properties, can be used as a component of filling in mining activity (Galos \& Uliasz-Bocheńczyk 2005, Madaj \& Klimas 2010). Studies have been conducted on the application of fly ashes and flotation wastes in the process of solidification of waste material contaminated with heavy metals (Banaszkiewicz \& Marcinkowski 2008).

Mineral waste, especially the carbonate one, can be considered as a potential mineral fertilizer when the minimum and maximum content requirements are met. The minimum content of calcium oxide for calcium fertilizers is $20 \%$ for type 09 , for type 01 the content of $\mathrm{CaO}$ reaches $80 \%$. With the lead and cadmium content being below 200 and $8 \mathrm{mg} / \mathrm{kg}$ respectively for all types of fertilizers at the same time, calculated per one kilogram of $\mathrm{CaO}$ (PN-C-87007-2:2000). When it comes to calcium-magnesium fertilizers the minimum content of $\mathrm{CaO}+\mathrm{MgO}$ equals from $40 \%$ to $75 \%$, with the minimum content of $\mathrm{MgO}$ from $8 \%$ to $25 \%$. With the maximum lead and cadmium content being $600 \mathrm{mg} / \mathrm{kg}$ and $15 \mathrm{mg} / \mathrm{kg}$ respectively at the same time, calculated per one kilogram of the sum of $\mathrm{CaO}$ and $\mathrm{MgO}$ (PN-C-87006-2:1996/Az1:2001).

\section{MINERAL WASTE PROPERTIES}

Chemical and mineralogical composition is a key factor when it comes to considering the potential direction that the commercial utilization of mineral waste could take. By being familiar with currently mined natural resources, the existence of mineral deposits or the regions where they can be found, we are able to determine what the composition of a given waste material is going to be and we can select appropriate research methodology accordingly, considering their commercial potential as well. Technological process requires that particular components have specific contents and their mutual proportion is also clearly determined. Specific technical regulations are specified in industry standards and industrial practice, and only when these requirements are met, we can consider the potential negative influence that using this type of waste may have in industrial processes.

From the point of view of environmental protection, those components of waste materials that can be transferred into the environment and cause potential damage, even though they only occur in small quantities, are of utmost importance. The information about the chemical composition of the material that is the source of waste is essential. Also the geochemical relations between the elements are important, as they help us determine the final composition of a waste material and choose appropriate methods of analysis. What is more, acts of law specify those elements and chemical compounds that should be regulated because of their detrimental impact on the environment. Heavy metals are examples of such pollutants that need to be treated with particular scrutiny regarding their content in waste materials. Heavy metals are those trace elements whose atomic mass is higher than that of sodium, and density exceeds $5 \mathrm{~g} / \mathrm{cm}^{3}$ (Kabata-Pendias \& Pendias 1999). In appendix 4 to Polish legal act Ustawa $z$ dnia 14 grudnia 2012 r. o odpadach, there are enumerated the components of waste materials that determine whether a specific type of waste would be considered hazardous. Among others, the list includes elements that are toxic and persistent in the environment, such as: As, $\mathrm{Cd}, \mathrm{Sb}, \mathrm{Hg}, \mathrm{Tl}, \mathrm{Pb}, \mathrm{Cr}(\mathrm{VI}), \mathrm{Ni}, \mathrm{Cu}, \mathrm{Zn}$. It is also crucial to study the elements that in their dissolved form can cause eutrophication (P, N) or environmental acidity $(\mathrm{Cl}, \mathrm{S})$. For example such situation can be observed as a result of pollutants leaching from waste materials.

\section{A REVIEW \\ OF ANALYTICAL METHODS USED IN THE STUDY OF WASTE MATERIALS}

When it comes to the choice of a method, the most important criterion is to select the one that makes it possible to collect the largest amount of data, simultaneously being time and cost effective. A short characteristic of featured methods is presented in Table 1.

A total chemical composition of a given material is the most fundamental parameter to be determined. More and more often a mineralogical composition is also determined since the phenomenon of polymorphism makes it possible to affect physical and chemical properties of a tested material. 


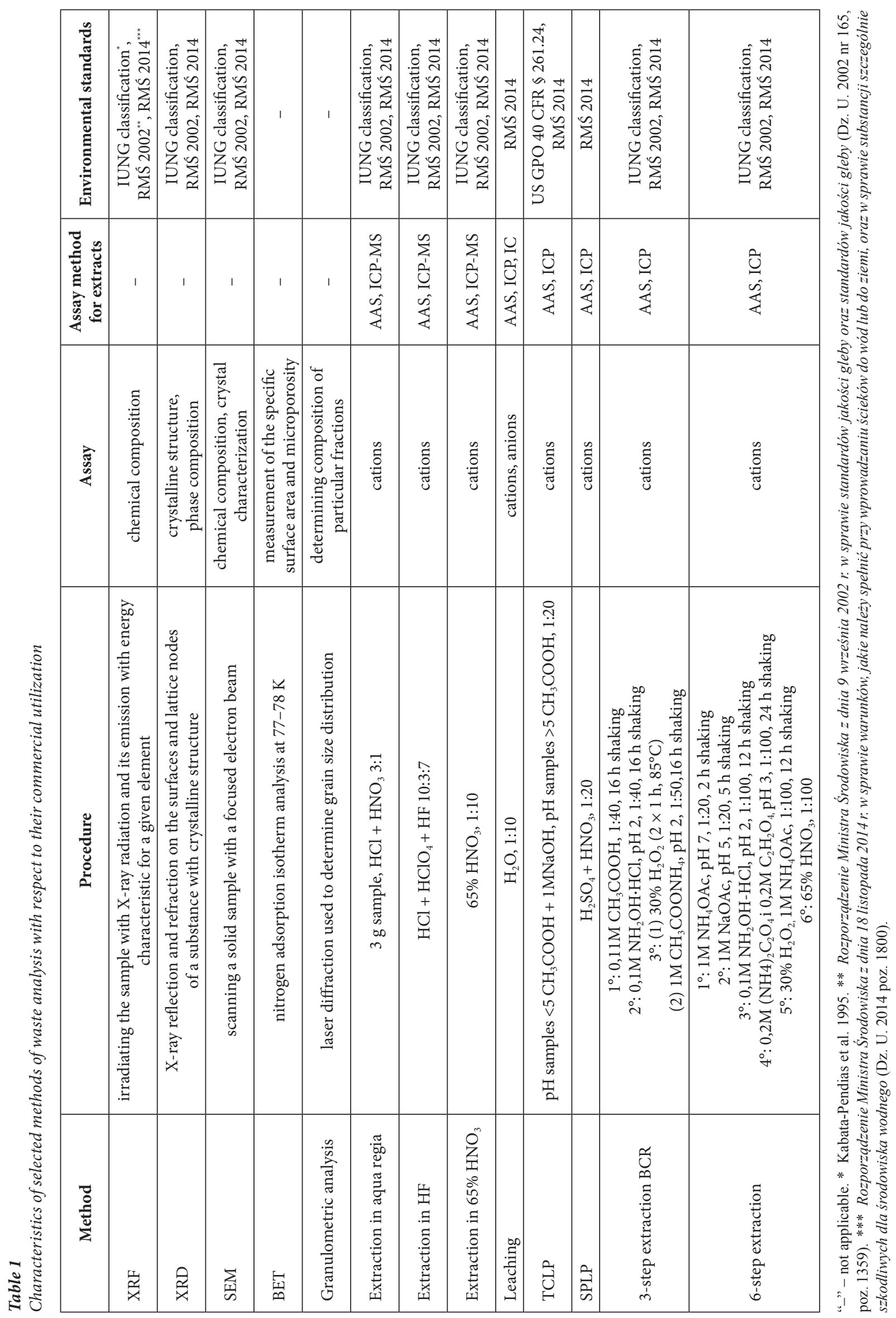


The most popular analyses that do not cause the destruction of the sample include following methods. The X-Ray Fluorescence method (XRF) determines the chemical composition of a tested material. The X-Ray Diffraction method (XRD), allows to identify crystalline structure, and also phase composition of an investigated material. The method of Scanning Electron Microscopy (SEM) informs us of the morphology, coarseness, size, crystal orientation and chemical composition. The result of XRD examination is a set of X-rays, their sequence corresponds to a specific crystalline structure (Bolewski \& Żabiński 1988, Gaweł \& Muszyński 1996). The obtained result is then compared against the catalogue (the database of the International Centre for Diffraction Data ICDD) or with published data in order to recognize the mineral structure. As a result of SEM method, microscopic images with the magnification of $10 \times$ to $200,000 \times$ are obtained and then used to determine mineralogical composition (Reed 1993).

In order to determine the total content of analysed elements or chemical compounds, methods that involve destruction of the sample and transfer of the components into a solution are also used. These methods are connected with the phenomenon in which compound content in the determined extract increases proportionally with the extraction strength of the reagent used. When it comes to extraction of trace elements (heavy metals) the methods used most often are (arranged according to the increasing strength of extraction): nitric acid, also with hydrogen peroxide (Ciszewski et al. 2013, 2014), aqua regia (PN-ISO 11466:2002), hydrofluoric acid (Kicińska 2009, 2011).

In order to find potential ways for waste utilization, textural and granulometric analyses are used. The most important textural features regarding the utilization of waste material are surface area and the structure and size of pores, which are crucial for sorption processes. Typically, the standard method used in this case is nitrogen adsorption isotherm analysis at $77 \mathrm{~K}$ calculated with the linear form of the adsorption isotherm BET equation (BrunauerEmmett-Teller). Grain-size distribution analysis, or granulometric analysis, determines the quantity of material in particular grain size fractions. Sieve analysis is the simplest procedure used there, it involves sifting the tested sample through a selection of sieves. However, more and more often the newest optical-electronic digital measurement methods are used (ISO 13320-2009, Holtzer et al. 2012). For instance, laser particle size analysis is used for the samples with the finest grain size or for those materials that during the sieve analysis went through the sieve with the mesh size of $0.5 \mathrm{~mm}$. During a single analysis grain-size distribution is determined and there is no need to use different analytical methods, and the discrepancies in the measurements are reduced (Loizeau et al. 1994). This method is not only time-effective, but also allows for the reduction in the size of the sample needed. Nevertheless, there are also some flaws when it comes to the evaluation of the finest grain fractions (clay particles) (Beuselinck et al. 1998). The result of the analysis is a grain distribution curve and the percentage content of individual fractions.

The parameters described are primarily used to determine whether a given material complies with technical requirements. Information about the total content of specific components is also necessary to evaluate the potential impact of waste on the environment. It needs to be pointed out that the total pollutant content does not indicate a real threat to the environment, as some pollutants may be present in the material in crystalline structure or hardly mobile forms. Consequently, the likelihood of these pollutants being transferred into the environment is relatively small (Siepak 1998, Niedzielski 2007). Therefore, when it comes to the impact on the environment, it is much more important to know what percentage of the total pollutant content is mobile or bioavailable. To learn this, different extraction methods are used and, depending on the strength of the extraction agent used, they cause leaching of elements from a particular bind form. In laboratory practice, the most commonly used tests are (arranged according to the increasing strength of extraction): Toxicity Characteristic Leaching Procedure (TCLP), Synthetic Precipitation Leaching Procedure (SPLP) and multistage extractions, most often a six-step extraction procedure and a three-step one (BCR).

In the Toxicity Characteristic Leaching Procedure distilled water is used as an extraction liquid. This test is specified in the Polish Standard and depending on the liquid to solid phase ratio $(\mathrm{L} / \mathrm{S})$, as well as, the grain size of the tested sample. Four parts of the aforementioned 
standard are distinguished (PN-EN 12457-1:2006, PN-EN 12457-2:2006, PN-EN 12457-3:2006, PN-EN 12457-4:2006).

The TCLP test is a testing procedure designed by US EPA in order to determine the mobility of organic and inorganic compounds present in liquid, solid and mixed waste materials. To transfer the pollutants into the solution acetic acid or the mixture of acetic acid and sodium hydroxide is used, depending on the $\mathrm{pH}$ of the tested waste material (US EPA 1992). The waste material that exceeds the expected value of a certain component is classified by means of TCLP procedure as hazardous waste. The test imitates the process of water filtration through deposited waste material, allowing us to determine the impact of the deposited waste on the environment by comparing the results with pollutant limit values for eluates. Waste material poses risk to the environment when the content of particular pollutants in eluates exceeds the limit values for TCLP test (Tab. 2).

Table 2

Permissible levels of selected elements in TCLP test eluates

\begin{tabular}{|c|c|}
\hline \multicolumn{2}{|c|}{ Permissible levels in TCLP test eluates* } \\
\hline metal & limit value $[\mathbf{m g} / \mathbf{L}]$ \\
\hline $\mathrm{Ag}$ & 5.0 \\
\hline $\mathrm{As}$ & 5.0 \\
\hline $\mathrm{Ba}$ & 100.0 \\
\hline $\mathrm{Cd}$ & 1.0 \\
\hline $\mathrm{Cr}$ & 5.0 \\
\hline $\mathrm{Hg}$ & 0.2 \\
\hline $\mathrm{Pb}$ & 5.0 \\
\hline $\mathrm{Se}$ & 1.0 \\
\hline
\end{tabular}

* US GPO 40 CFR $₫ 261.24$.

The SPLP method (US EPA 1994) was designed to evaluate the mobility of waste material components with solution of which the chemical composition resembles that of precipitation. This time, the mixture of sulphuric and nitric acid is used to transfer the pollutants into the solution. The test simulates the release components from waste in a very short time after the application of the extraction liquid. This test is recommended when we want to evaluate the effects of immediate or short-term leaching on a waste material exposed to atmospheric conditions.

The six-step sequential extraction procedure developed by Förstner \& Calmano (1982) is a modified version of Tessier's method from 1972 (Calmano 1989). It is used to determine the quantity of heavy metals bounded in particular forms. Six steps of metal binding are distinguished: step 1 - metals in exchangeable positions, step 2 - metals bound with carbonates, step 3 - metals bound with and Mn oxides, step 4 - metals bound with amorphous Fe oxides, step 5 - metals bound with amorphous sulphides and organic matter, and step 6 - metals associated with crystalline structure of minerals, i.e. residuals.

The BCR three-step sequential extraction procedure is a very popular simplification of multistep extraction methods (Tessier et al. 1979, Quevauviller et al. 1997). This method makes it possible to determine metal bindings in the following fractions: step 1 - exchangeable and carbonate fraction, step 2 - reducible fraction, metals bound with iron and manganese oxides, step 3 oxidizable fraction, metals bound with organic matter and sulfides. Additionally, this method also distinguishes the fourth step, so-called residue, where aqua regia (PN-ISO 11466:2002) or concentrated nitric acid (might be with hydrogen peroxide) is used on the residual material in order to extract metals associated with crystalline structure of minerals (Larner et. al 2006, Rao et al. 2008). The results obtained from sequential extraction analyses translate into information on bioavailability, mobility and metal transport in the environment (Szumska \& Gworek 2009, Jeske \& Gworek 2011)

\section{THE INTERPRETATION OF WASTE ANALYSIS RESULTS IN THE CONTEXT OF COMMERCIAL UTILIZATION BASED ON POLISH ENVIRONMENTAL LEGAL STANDARDS}

Mentioned before fundamental legal act on waste (Ustawa $z$ dnia 14 grudnia 2012 r. o odpadach) regulates the problem of waste management in Poland. 
Annexes 3 and 4 to the act respectively delineate the properties and components that qualify certain waste materials as hazardous. Moreover, the major implementing act on waste catalogue (Rozporzadzenie Ministra Środowiska $z$ dnia 9 grudnia 2014 r.w sprawie katalogu odpadów) divides waste materials into 20 groups, specifying their subgroups and types. Waste catalogue also contains the so-called list of hazardous waste materials that are marked with the symbol of ${ }^{*}$ after a six-digit code. The waste materials marked as hazardous should be (to enable their utilization) reclassified as non-hazardous by proving that they do not exhibit any hazardous properties.

Table 3

Permissible levels of selected elements in leachates from waste

\begin{tabular}{|c|c|c|c|}
\hline \multicolumn{4}{|c|}{ Permissible levels in leachates ${ }^{*}$} \\
\hline cations & $\begin{array}{c}\text { limit value } \\
{[\mathrm{mg} / \mathrm{L}]}\end{array}$ & anions & $\begin{array}{c}\text { limit value } \\
{[\mathrm{mg} / \mathrm{L}]}\end{array}$ \\
\hline As & 0.1 & $\mathrm{Cl}^{-}$ & 1000.0 \\
\hline $\mathrm{Ba}$ & 2.0 & $\mathrm{~F}^{-}$ & 25.0 \\
\hline $\mathrm{Cd}$ & 0.05 & $\mathrm{NO}_{2}^{-}$ & 1.0 \\
\hline Co & 0.1 & $\mathrm{NO}_{3}^{-}$ & 30.0 \\
\hline $\mathrm{Cr}^{6+}$ & 0.1 & $\mathrm{~S}^{2-}$ & 0.2 \\
\hline $\mathrm{Cr}_{\text {og }}$ & 0.5 & $\mathrm{SO}_{4}{ }^{2-}$ & 500.0 \\
\hline $\mathrm{Cu}$ & 0.1 & & \\
\hline $\mathrm{Fe}_{\mathrm{og}}$ & 10.0 & & \\
\hline $\mathrm{Hg}$ & 0.06 & & \\
\hline K & 80.0 & & \\
\hline $\mathrm{Na}$ & 800.0 & & \\
\hline $\mathrm{Ni}$ & 0.1 & & \\
\hline $\mathrm{P}$ & 2.0 & & \\
\hline $\mathrm{Pb}$ & 0.1 & & \\
\hline $\mathrm{Sb}$ & 0.3 & & \\
\hline Sn & 0.1 & & \\
\hline $\mathrm{Tl}$ & 1.0 & & \\
\hline $\mathrm{Zn}$ & 2.0 & & \\
\hline
\end{tabular}

* Rozporzadzenie Ministra Środowiska $z$ dnia 18 listopada $2014 \mathrm{r}$. w sprawie warunków, jakie należy spetnić przy wprowadzaniu ścieków do wód lub do ziemi, oraz w sprawie substancji szczególnie szkodliwych dla środowiska wodnego (Dz. U. 2014 poz. 1800).
When it comes to mineral waste, special consideration should be given to the content of toxic elements in them, especially to heavy metals. Wastes come into contact with precipitation, which is why pollutants may be leached and transferred into surface waters and soil. It should be noted that in leachates there are also present anions that can cause acidification of the environment, as they are transferred in large quantities into the environment.

The limit values for particular pollutants in leachates from waste (Tab. 3) can be interpreted according to the regulation on the conditions to be met as regards the release of sewage into the water or onto the land and on the substances that are particularly harmful to the aquatic environment (Rozporzadzenie Ministra Środowiska $z$ dnia 18 listopada 2014 r. w sprawie warunków, jakie należy spetnić przy wprowadzaniu ścieków do wód lub do ziemi, oraz $w$ sprawie substancji szczególnie szkodliwych dla środowiska wodnego).

When it comes to using waste material as soil fertilizers or to neutralize land, the guidelines determining the limit values for pollution levels in soils used for agricultural purposes may be used (Tab. 4). They were prepared by the Institute of Soil Science and Plant Cultivation in Puławy (Instytut Uprawy Nawożenia i Gleboznawstwa w Puławach - IUNG) (Kabata-Pendias et al. 1995). On the basis of these classification, six levels of soil contamination with heavy metals were distinguished: 0 - not contaminated soils, I - soils with an increased level of heavy metal content, II slightly contaminated soils, III - moderately contaminated soils, IV - heavily contaminated soils, $\mathrm{V}$ - most heavily contaminated soils. According to sulphur four levels of contamination in soils were developed: I - low, II - moderate, III - high, IV - anthropogenic intensified. In accordance to PAHs six levels of soil contamination were distinguished: 0 - PAH content neutral, I - content above normal, II - slightly contaminated soils, III - contaminated soils, IV - heavily contaminated soils, $\mathrm{V}$ - most heavily contaminated soils. Using wastes to improve soil properties would involve focusing on maintaining the total level of contamination introduced with a given waste material below the limit values. It is also important to remember that apart from not exceeding the total limit value, other guidelines should be introduced. 
Table 4

Permissible levels of selected elements in soils used for agricultural purposes

\begin{tabular}{|c|c|c|c|c|c|c|}
\hline \multirow{2}{*}{ Compound } & \multicolumn{6}{|c|}{ Classes of soil contamination } \\
\hline & $\mathbf{0}$ & I & II & III & IV & V \\
\hline \multicolumn{7}{|c|}{ [mg/kg d. m.] } \\
\hline $\mathrm{Cd}$ & $0.3-1$ & $1-3$ & $2-5$ & $3-10$ & $5-20$ & $>5->20$ \\
\hline $\mathrm{Cu}$ & $10-25$ & $30-70$ & $50-100$ & $80-150$ & $300-750$ & $>300->750$ \\
\hline $\mathrm{Cr}$ & $20-50$ & $40-80$ & $80-200$ & $150-500$ & $300-1000$ & $>300->1000$ \\
\hline $\mathrm{Ni}$ & $10-50$ & $30-75$ & $50-100$ & $100-300$ & $400-1000$ & $>400->1000$ \\
\hline $\mathrm{Pb}$ & $20-60$ & $70-150$ & $100-500$ & $500-2000$ & $2500-7000$ & $>2500->7000$ \\
\hline $\mathrm{Zn}$ & $50-100$ & $100-250$ & $200-500$ & $700-2000$ & $1500-5000$ & $>1500->5000$ \\
\hline \multirow{5}{*}{$\mathrm{S}-\mathrm{SO}_{4}$} & & $<15$ & $16-25$ & $26-35$ & $>35$ & \\
\hline & & $<20$ & $21-30$ & $31-40$ & $>40$ & \\
\hline & & $<25$ & $26-35$ & $36-50$ & $>50$ & \\
\hline & & $<30$ & $31-50$ & $51-100$ & $>100$ & \\
\hline & & $<50$ & $51-100$ & $100-150$ & $>150$ & \\
\hline \multirow{5}{*}{$S_{o g}$} & & $<150$ & $160-500$ & $510-1000$ & $>1000$ & \\
\hline & & $<200$ & $210-750$ & $760-1500$ & $>1500$ & \\
\hline & & $<250$ & $260-1000$ & $1010-2000$ & $>2000$ & \\
\hline & & $<500$ & 510-1000 & $1010-2500$ & $>2500$ & \\
\hline & & $<1000$ & $1010-2500$ & $2510-4500$ & $>4500$ & \\
\hline
\end{tabular}

* depending on the type of soil (Kabata-Pendias et al. 1995).

\section{Table 5}

Permissible levels of selected elements in soils and ground ( $\mathrm{mg} / \mathrm{kg}$ dry mass)

\begin{tabular}{|c|c|c|c|c|c|c|c|c|c|c|}
\hline \multirow{7}{*}{ Metal } & \multicolumn{9}{|c|}{ Permissible levels in soils and ground ${ }^{*}$} & \multirow{7}{*}{$\begin{array}{c}\text { Limit values in soils }^{* *} \\
\text { where, the use of sewage } \\
\text { for agricultural purposes is } \\
\text { allowed }^{* * *}\end{array}$} \\
\hline & \multirow{6}{*}{ group A } & \multicolumn{5}{|c|}{ group B } & \multicolumn{3}{|c|}{ group C } & \\
\hline & & \multicolumn{8}{|c|}{ depth [m BGL] } & \\
\hline & & $0-0.3$ & \multicolumn{2}{|c|}{$0.3-15$} & & & $0-2$ & \multicolumn{2}{|c|}{$2-15$} & \\
\hline & & \multicolumn{8}{|c|}{ water permeability $[\mathrm{m} / \mathrm{s}]$} & \\
\hline & & \multirow{2}{*}{$0-0.3$} & up to & below & up to & below & \multirow{2}{*}{$0-2$} & up to & below & \\
\hline & & & \multicolumn{2}{|c|}{$1 \cdot 10^{-7}$} & \multicolumn{2}{|c|}{$1 \cdot 10^{-7}$} & & \multicolumn{2}{|c|}{$1 \cdot 10^{-7}$} & \\
\hline As & 20 & 20 & 20 & 25 & 25 & 55 & 60 & 25 & 100 & - \\
\hline $\mathrm{Ba}$ & 200 & 200 & 250 & 320 & 300 & 650 & 1000 & 300 & 3000 & - \\
\hline $\mathrm{Cd}$ & 1 & 4 & 5 & 6 & 4 & 10 & 15 & 6 & 20 & $0.5-3.0$ \\
\hline Co & 20 & 20 & 30 & 60 & 50 & 120 & 200 & 50 & 300 & - \\
\hline $\mathrm{Cr}$ & 50 & 150 & 150 & 190 & 150 & 380 & 500 & 150 & 800 & $30-100$ \\
\hline $\mathrm{Cu}$ & 30 & 150 & 100 & 100 & 100 & 200 & 600 & 200 & 1000 & $20-75$ \\
\hline
\end{tabular}


Table 5 cont.

\begin{tabular}{|c|c|c|c|c|c|c|c|c|c|c|}
\hline $\mathrm{Hg}$ & 0.5 & 2 & 3 & 5 & 4 & 10 & 30 & 4 & 50 & $0.7-1.5$ \\
\hline $\mathrm{Ni}$ & 35 & 100 & 50 & 100 & 70 & 210 & 300 & 70 & 500 & $10-50$ \\
\hline $\mathrm{Pb}$ & 50 & 100 & 100 & 200 & 100 & 200 & 600 & 200 & 1000 & $20-80$ \\
\hline $\mathrm{Sn}$ & 20 & 20 & 30 & 50 & 40 & 300 & 350 & 40 & 300 & - \\
\hline $\mathrm{Zn}$ & 100 & 300 & 350 & 300 & 300 & 720 & 1000 & 300 & 3000 & $60-180$ \\
\hline
\end{tabular}

* Rozporządzenie Ministra Środowiska z dnia 9 września 2002 r. w sprawie standardów jakości gleby oraz standardów jakości ziemi (Dz. U. $2002 \mathrm{nr}$ 165, poz. 1359).

** depending on the type of soil.

*** Rozporzq̨dzenie Ministra Środowiska z dnia 18 listopada 2014 r. w sprawie warunków, jakie należy spełnić przy wprowadzaniu ścieków do wód lub do ziemi, oraz w sprawie substancji szczególnie szkodliwych dla środowiska wodnego (Dz. U. 2014, poz. 1800).

“_” - not applicable.

Primarily regarding the potential leaching of contaminations from solid wastes must be met and measures preventing waste materials from being blown around by wind or moved by other agents or living organisms from the surface of the ground. When there is soil other than that used for agricultural purposes, the regulation on the standards for soil and ground quality (Rozporzadzenie Ministra Środowiska $z$ dnia 9 września 2002 r. w sprawie standardów jakości gleby oraz standardów jakości ziemi) may be applied. For each of the three types of soils distinguished in the regulation, with reference made to the depth (below ground level) and their water permeability, there are limit values given for specific contaminations (Tab. 5). Group A covers grounds in protected areas defined within the meaning of water law act (Ustawa $z$ dnia 18 lipca 2001 r. Prawo wodne) and the act on environmental protection (Ustawa $z$ dnia 16 kwietnia $2004 r$. o ochronie przyrody). Group B covers agricultural areas (with some exceptions). Group C refers to industrial areas, surface mining land in use and transportation areas.

\section{CONCLUSIONS}

When it comes to extensive, i.e. regarding great quantities, and long-term usage of industrial wastes, the identical composition of waste material coming from different batches is of the essence. Unfortunately, this condition is not always fulfilled, therefore chemical composition analyses need to be carried out for monitoring purposes. For the same reason the waste material used should also be tested to check whether the parameters of a given batch are within the limit values defined by the standards.

In order to save time spent on preparing samples for testing, and to avoid the destruction of the material, the methods that preserve the samples will be favoured. However, they can only be used to determine the total content of particular components. XRF method determines the element content in the sample in the form of oxides. XRF method is relatively cost-effective and the samples can be easily prepared (Ene et al. 2010).

Out of the methods that involve the destruction of the sample and provide information on the total content of the components tested, extractions with concentrated acids may be employed. The extraction in concentrated nitric acid is a method that allows to evaluate the total content of the analysed element in an environmental sample. Nevertheless, drastic $\mathrm{pH}$ conditions present in this method can never be observed in the environment. Therefore, this procedure can be used to determine a content of elements in tested sample that is potentially subject to leaching. Decomposition in nitric acid is used as the $6^{\text {th }}$ step of sequential extraction, at this step metals and sulfides bound to crystalline structure of minerals are extracted (Calmano 1989). Decomposition in aqua regia is supposed to, just like the decomposition in $\mathrm{HNO}_{3}$, determine the "total" content of metals in the sample. This method is used as a $4^{\text {th }}$ step in BCR extraction, where in the residue from the $3^{\text {rd }}$ step metals bound with the residual phase are additionally extracted. Potentially, the highest total content can be obtained during the extraction with $\mathrm{HF}$ or $\mathrm{HClO}_{4}$. Concentrations are going to be higher than in the case of extraction by means 
of aqua regia and $\mathrm{HNO}_{3}$ because $\mathrm{HF}$ can dissolve almost all types of silicates. However, due to extremely high toxicity of HF, and explosive properties of $\mathrm{HClO}_{4}$ they are rarely used (Szumska \& Gworek 2009, Jeske \& Gworek 2011).

Leaching tests can provide us information on the mobility of the analysed components and the quantity of elements bound to particular phases. Depending on the needs, tests with various complexity levels can be used, from the simplest - the leaching test, which is unfortunately the least informative one, to the most complicated and time-consuming four- and six-step methodologies, which can also provide most data on the types of binding and mobility of particular components. The TCLP test seems to be most appropriate to simulate the conditions of a long-term leaching that waste materials in a landfill are exposed to (Shieh 2001, Hageman et al. 2015) and best for organic contaminations. The SPLP test is preferred when the content of metals in a sample is analysed because of a lower $\mathrm{pH}$ and lack of complexing agents in the extraction liquid (Lackovic et al. 1997). This test is much more suitable for leaching simulations where the leaching agent is applied directly before the leaching process, as it is the case with precipitation (Hageman et al. 2015).

The above mentioned analysis methods are intended to facilitate waste characterisation with respect to their effect on the environment when used for commercial purposes. An individual method is never good enough to determine the full extent of environmental impact. It is therefore recommended to apply several methods in a logical sequence, depending on the type of waste material and its purpose. Broadly speaking, we can suggest the following succession of tests: XRF (qualitative composition and the percentage of elements), TCLP/SPLP test (leaching of contaminants in the conditions corresponding to the natural ones, depending on the purpose of the waste), BCR extraction (binding forms of particular contaminants), extraction with aqua regia (total content of contaminants in the waste material), BET (specific surface area, the distribution and size of pores, depending on the purpose), laser particle size analysis (gradation and its distribution, depending on the purpose).

Sustainable waste management implies waste disposal only when all other measures have been exhausted. When it comes to mineral waste, there are many potential applications, but before any of them are employed, an appropriate environmental characteristics is required. Familiarity with the range of analysis methods available and the choice of the right one is crucial in the process of searching for and utilizing mineral waste commercially.

This research has been funded by AGH University of Science and Technology Statutory Research No. 11.11.140.199.

\section{REFERENCES}

Andziak J. \& Sobczyński P, 2001. Ścierniwo konwertorowo-wielkopiecowe substytutem piasku kwarcowego w obróbce strumieniowo-ściernej. Ochrona przed Korozja, 9, 234-239.

Banaszkiewicz K. \& Marcinkowski T., 2008. Stosowanie popiołów lotnych i odpadów flotacyjnych do zestalania odpadów zawierających metale ciężkie. Infrastruktura i Ekologia Terenów Wiejskich, 1, 19-29.

Batchelor B., 2006. Overview of waste stabilization with cement. Waste Management, 26, 689-698.

Beuselinck L., Govers G., Poesen J., Degraer G. \& Froyen L, 1998. Grain-size analysis by laser diffractometry: comparison with the sieve-pipette method. Catena, 32, 193-208.

Bolewski A. \& Żabiński W., 1988. Metody badań minerałów i skat. Wydawnictwa Geologiczne, Warszawa.

Calmano W., 1989. Schwermetallen in kontaminierten Feststoffen. Technische Universität Hamburg-Harburg.

Ciszewski D., Aleksander-Kwaterczak U., Pociecha A., Szarek-Gwiazda E., Waloszek A. \& Wilk-Woźniak E., 2013. Small effects of a large sediment contamination with heavy metals on aquatic organisms in the vicinity of an abandoned lead and zinc mine. Environmental Monitoring and Assessment, 185, 12, 9825-9842.

Ciszewski D., Bijata P. \& Klimek K., 2014. Reconstructions of post-mining attenuation of heavy metal pollution in sediment of the Zlatý Potok, Eastern Sudety Mts. Carpathian Journal of Earth and Environmental Sciences, 9, 4, 109-120.

Dehghani A. \& Bridjanian H., 2010. Flue gas desulfurization methods to conserve the environment. Petroleum \& Coal, 52, 4, 220-226.

Ene A., Bosneaga A. \& Georgescu L., 2010. Determination of heavy metals in soils using XRF technique. Romanian Journal of Physics, 55, 7-8, 815-820.

Förstner U. \& Calmano W., 1982. Bindungsformen von Schwermetallen in Baggerschlämmen. Vom Wasser, 59, 83-92.

Franus W., Wdowin M. \& Franus M., 2014. Synthesis and characterization of zeolites prepared from industrial fly ash. Environmental Monitoring and Assessment, 186, 9, 5721-5729.

Galos K., 2008. Źródła, produkcja i znaczenie gospodarcze kruszyw sztucznych w Polsce. Prace Naukowe Instytutu Górnictwa Politechniki Wrocławskiej. Konferencje, 121, 50, 45-58. 
Galos K. \& Nieć M., 2009. Ogólna charakterystyka mineralnych surowców odpadowych. [in:] Ney R. (red.), Mineralne surowce odpadowe, series: Surowce Mineralne Polski, Wydawnictwo Instytutu GSMiE PAN, Kraków.

Galos K. \& Uliasz-Bocheńczyk A., 2005. Źródła i użytkowanie popiołów lotnych ze spalania węgli w Polsce. Gospodarka Surowcami Mineralnymi, 21, 1, 23-42.

Gaweł A. \& Muszyński M., 1996. Tablice do identyfikacji minerałów metodą rentgenograficzną. Wydawnictwa $\mathrm{AGH}$, Kraków.

Góralczyk S., Mazela A., Uzunow E. \& Naziemiec Z., 2009. Kruszywa lekkie z osadów ściekowych i odpadów mineralnych. Prace Naukowe Instytutu Górnictwa Politechniki Wrocławskiej. Studia i Materiały, 125, 35, 105-112.

Gruchot A. \& Zawisza E., 2007. Badania parametrów geotechnicznych wybranych odpadów przemysłowych w aspekcie wykorzystania ich do budownictwa drogowego. Przeglad Górniczy, 63, 10, 26-32.

GUS, 2014. Ochrona środowiska 2014. Główny Urząd Statystyczny, Warszawa.

Hageman P.L., Seal R.R., Diehl S.F., Piatak N.M. \& Lowers H.A., 2015. Evaluation of selected static methods used to estimate element mobility, acid-generating and acid-neutralizing potentials associated with geologically diverse mining wastes. Applied Geochemistry, doi: 10.1016/j.apgeochem.2014.12.007.

Helios-Rybicka E., Jarosz-Krzemińska E. \& Gawlicki M., 2013. Zastosowanie zneutralizowanych, potrawiennych materiałów odpadowych $w$ postaci szlamów uzyskanych $w$ wyniku trawienia powierzchni metalicznych. Patent PL216497B1.

Holtzer M., Dańko R. \& Skrzyński M., 2012. Badanie skuteczności klasyfikacji w oparciu o wykorzystanie metody laserowego pomiaru wielkości ziaren. Archives of Foundry Engineering, 12, 1/2012, 63-68.

ISO 13320-2009. Particle size analysis - Laser diffraction methods.

Jeske A. \& Gworek B., 2011. Przegląd metod oznaczania biodostępności i mobilności metali ciężkich w glebach. Ochrona Środowiska i Zasobów Naturalnych, 49, 209-218.

Kabata-Pendias A. \& Pendias H., 1999. Biogeochemia pierwiastków śladowych. Wydawnictwo Naukowe PWN Warszawa.

Kabata-Pendias A., Motowicka-Terelak T., Terelak H. \& Witek T., 1993. Ocena stopnia zanieczyszczenia gleb i roślin metalami ciężkimi i siarka - ramowe wytyczne dla rolnictwa. Wydawnictwo Instytutu Upraw Nawożenia i Gleboznawstwa, Puławy, P(53), 1-20.

Kabata-Pendias A., Piotrowska M., Motowicka-Terelak T., Maliszewska-Kordybach B., Filipiak K., Krakowiak A. \& Pietruch C., 1995. Podstawy oceny chemicznego zanieczyszczenia gleb. Metale ciężkie, siarka i WWA. Series: Biblioteka Monitoringu Środowiska, Państwowa Inspekcja Ochrony Środowiska, Warszawa.

Kicińska A., 2009. Arsen i tal w glebach i roślinach rejonu Bukowna. Ochrona Środowiska i Zasobów Naturalnych, 40, 199-208.

Kicińska A., 2011. Formy występowania oraz mobilność cynku, ołowiu i kadmu w glebach zanieczyszczonych przez przemysł wydobywczo-metalurgiczny. Ochrona Środowiska i Zasobów Naturalnych, 49, 152-162.
Kicińska A., Adamiec E. \& Gruszecka-Kosowska A., 2014. Współczesne uwarunkowania inżynierii i ochrony środowiska w Polsce. Wydawnictwa AGH, Kraków.

Kohutek Z. (red.), 2008. Beton przyjazny środowisku. Stowarzyszenie Producentów Betonu Towarowego w Polsce, Kraków.

Król A., 2006. Beton i jego składniki w aspekcie wymagań środowiskowych. Budownictwo, Technologie, Architektura, 1, 53-56.

Lackovic J.A., Nikolaidis N.P., Chheda P., Carley R.J. \& Patton E., 1997. Evaluation of batch leaching procedures for estimating metal mobility in glaciated soils. Ground Water Monitoring and Remediation, 17, 3, 231-240.

Larner B.L., Seen A.J. \& Townsend A.T., 2006. Comparative study of optimised BCR sequential extraction scheme and acid leaching of elements in the certified reference material NIST 2711. Analytica Chimica Acta, 556, 444-449.

Li X.D., Poon C.S, Sun H., Lo I.M.C. \& Kirk D.W., 2001. Heavy metal speciation and leaching behaviors in cement based solified/stabilized waste materials. Journal of $\mathrm{Ha}$ zardous Materials, A82, 215-230.

Loizeau J.L., Arbouille D., Santiago S. \& Vernet J-P., 1994. Evaluation of a wide range laser diffraction grain size analyser for use with sediments. Sedimentology, 41, 353-361.

Madaj M. \& Klimas W., 2010. Popioły lotne jako składniki zaczynów spoiwowych transportowanych hydraulicznie z powierzchni. Budownictwo Górnicze i Tunelowe, 2010, 1 , $47-51$.

Małolepszy J., Gawlicki M., Brylicki W., Deja J., Żurawski S., Szczepaniak K., Mrozowicz J. \& Rutkowski J., 1994. Zestaw surowcowy do wytwarzania klinkieru portlandzkiego. Patent PL 162748 B1.

Niedzielski P., 2007. Narzędzia i koncepcje analizy specjacyjnej. Wydawnictwo UAM, Poznań.

Özyuğuran A., Ersoy-Meriçboyu A., 2012. Using hydrated lime and dolomite for sulfur dioxide removal from flue gases. Chemical Engineering Transactions, 29, 1051-1056.

PN-C-87006-2:1996/Az1:2001P. Nawozy sztuczne wapniowo-magnezowe. Podział, oznaczenie i wymagania.

PN-C-87007-2:2000P. Nawozy sztuczne wapniowe. Klasyfikacja, oznaczenie i wymagania.

PN-EN 12457-1:2006P. Charakteryzowanie odpadów. Wymywanie. Badanie zgodności $w$ odniesieniu do wymywania ziarnistych materiałów odpadowych i osadów. Część 1: Jednostopniowe badanie porcjowe przy stosunku cieczy do fazy stałej $2 \mathrm{l} / \mathrm{kg} w$ przypadku materiałów o wysokiej zawartości fazy stałej i wielkości cząstek poniżej $4 \mathrm{~mm}$ (bez redukcji lub z redukcja wielkości).

PN-EN 12457-2:2006P. Charakteryzowanie odpadów. Wymywanie. Badanie zgodności w odniesieniu do wymywania ziarnistych materiałów odpadowych i osadów. Czesść 2: Jednostopniowe badanie porcjowe przy stosunku cieczy do fazy stałej $10 \mathrm{l} / \mathrm{kg} w$ przypadku materiałów o wielkości czastek poniżej $4 \mathrm{~mm}$ (bez redukcji lub z redukcja wielkości).

PN-EN 12457-3:2006P. Charakteryzowanie odpadów. Wymywanie. Badanie zgodności w odniesieniu do wymywania ziarnistych materiałów odpadowych i osadów. Czesść 3: Dwustopniowe badanie porcjowe przy stosunku cieczy do fazy stałej $2 \mathrm{l} / \mathrm{kg}$ i $8 \mathrm{l} / \mathrm{kg}$ dla materiałów o wysokiej zawartości fazy stałej i wielkości cząstek poniżej $4 \mathrm{~mm}$ (bez redukcji lub z redukcją wielkości). 
PN-EN 12457-4:2006P. Charakteryzowanie odpadów. Wymywanie. Badanie zgodności w odniesieniu do wymywania ziarnistych materiałów odpadowych i osadów. Część 4: Jednostopniowe badanie porcjowe przy stosunku cieczy do fazy stałej $10 \mathrm{l} / \mathrm{kg} w$ przypadku materiałów o wielkości cząstek poniżej $10 \mathrm{~mm}$ (bez redukcji lub z redukcja wielkości).

PN-ISO 11466:2002. Jakość gleby. Ekstrakcja pierwiastków śladowych rozpuszczalnych w wodzie królewskiej.

PN-S-96011:1998P. Drogi samochodowe. Stabilizacja gruntów wapnem do celów drogowych.

Quevauviller Ph., Rauret G., Lopez-Sanchez J.F., Rubio R., Ure A. \& Muntau H., 1997. Certification of trace metal extractable contents in a sediment reference material (CRM 601) following a three-step sequential extraction procedure. The Science of the Total Environment, 205, 223-234.

Rao C.R.M., Sahuquillo A. \& Lopez Sanchez J.F., 2008. A Review of the Different Methods Applied in Environmental Geochemistry For Single and Sequential Extraction of Trace Elements in Soils and Related Materials. Water, Air and Soil Pollution, 189, 291-333.

Reed S.J.B., 1993. Electron Microscope Analysis. $2^{\text {nd }}$ ed. Cambridge University Press.

Rosik-Dulewska C., 2012. Podstawy gospodarki odpadami. Wydawnictwo Naukowe PWN, Warszawa.

Rozporzadzenie Ministra Środowiska z dnia 9 września 2002 roku $w$ sprawie standardów jakości gleby oraz standardów jakości gleby. Dz. U. 2002 nr 165, poz. 1359.

Rozporzadzenie Ministra Środowiska $z$ dnia 18 listopada 2014 w sprawie warunków, jakie należy spetnić przy wprowadzaniu ścieków do wód lub do ziemi, oraz w sprawie substancji szczególnie szkodliwych dla środowiska wodnego. Dz. U. 2014 poz. 1800.

Rozporzadzenie Ministra Środowiska $z$ dnia 9 grudnia 2014 roku w sprawie katalogu odpadów. Dz. U. 2014 poz. 1923.

Shieh C.S., 2001. Criteria of selecting Toxicity Characteristic Leaching Procedure (TCLP) and Synthetic Precipitation Leaching Procedure (SPLP) tests to characterize special wastes. Final Report.

Siepak J., 1998. Analiza specjacyjna metali w próbkach wód i osadów dennych. Wydawnictwo UAM, Poznan.

Sybilski D. \& Kraszewski C., 2004. Ocena i badania wybranych odpadów przemysłowych do wykorzystania w kon- strukcjach drogowych. Etap I. Wydawnictwo IBDiM, Warszawa.

Szumska M. \& Gworek B., 2009. Metody oznaczania frakcji metali ciężkich w osadach ściekowych. Ochrona Środowiska i Zasobów Naturalnych, 41, 42-63.

Szymański E. \& Kołakowski J., 1992. Materiały budowlane z technologia betonu. Część 2. Series: Skrypty - Politechnika Białostocka, Wydawnictwa Politechniki Białostockiej, Białystok.

Tessier A., Campbell P.G.C. \& Bisson M., 1979. Sequential extraction procedure for the speciation of particulate trace metals. Analytical Chemistry, 51, 7, 344-351.

US EPA, 1992. TCLP, Method 1311, Rev 0. In SW-846: Test Methods for Evaluating Solid Waste. Physical/Chemical Methods, Office of Solid Waste, Washington, [on-line:] http://www.epa.gov/osw/hazard/testmethods/sw846/ pdfs/1311.pdf [access: 15.03.2015].

US EPA, 1994. SPLP, Method 1312, Rev 0. In SW-846: Test Methods for Evaluating Solid Waste. Physical/Chemical Methods, Office of Solid Waste, Washington, [on-line:] http://www.epa.gov/osw/hazard/testmethods/sw846/ pdfs/1312.pdf [access: 15.03.2015].

US GPO 40 CFR $\$ 261.24$. Toxicity Characteristic. [on-line:] http://www.gpo.gov/fdsys/pkg/CFR-2012-title40vol27/xml/CFR-2012-title40-vol27-part261.xml\#seqnum261.24 [access: 15.03.2015].

Ustawa $z$ dnia 18 lipca 2001 r. Prawo wodne. Dz. U. 2001 nr 115, poz. 1229 with amendments.

Ustawa $z$ dnia 14 grudnia 2012 r. o odpadach. Dz. U. 2013 poz. 21 with amendments.

Ustawa $z$ dnia 16 kwietnia 2004 r. o ochronie przyrody. Dz. U. $2004 \mathrm{nr}$ 92, poz. 880 with amendments.

Wdowin M., Franus W. \& Panek R., 2012. Preliminary results of usage possibilities of carbonate and zeolitic sorbents in $\mathrm{CO}_{2}$ capture. Fresenius Environmental Bulletin, $21,12,3726-3734$.

Wdowin M. \& Gruszecka A., 2012. Charakterystyka mineralogiczno-chemiczna i teksturalna odpadów poflotacyjnych z przemysłu $\mathrm{Zn}$ - $\mathrm{Pb}$ pod kątem dalszych rozważań wykorzystania ich jako sorbentów. Gospodarka Surowcami Mineralnymi, 28, 3, 55-69.

Żygadło M., Seweryn A. \& Woźniak M., 2010. Synteza zeolitów na bazie popiołów lotnych $\mathrm{z}$ wybranych instalacji odzysku ciepła. Archiwum Gospodarki Odpadami i Ochrony Srodowiska, 12, 1, 15-26. 